\title{
Clear Cell Sarcoma-like Tumor of the Gastrointestinal Tract: Clinical Outcome and Pathologic Features of a Molecularly Characterized Tertiary Center Case Series
}

\author{
MICHELA LIBERTINI ${ }^{1}$, KHIN THWAY $^{1}$, JONATHAN NOUJAIM ${ }^{2}$, FLORIAN PULS ${ }^{3}$, \\ CHRISTINA MESSIOU $^{1}$, CYRIL FISHER $^{1}$ and ROBIN L. JONES ${ }^{1}$ \\ ${ }^{1}$ Sarcoma Unit, The Royal Marsden NHS Foundation Trust and Institute of Cancer Research, London, U.K.; \\ ${ }^{2}$ Sarcoma Unit, Maisonneuve-Rosemont Hospital, Montreal, Canada; \\ ${ }^{3}$ Department of Clinical Pathology and Genetics, Sahlgrenska University Hospital, Gothenburg, Sweden
}

\begin{abstract}
Background/Aim: Clear cell sarcoma-like tumor of the gastrointestinal tract (CCSLTGT) is a very rare and relatively recently characterized mesenchymal neoplasm arising within the wall of the small bowel, stomach, or large bowel, predominantly in adolescents and young adults. Only few anecdotal reports or small series have been published and a consensus on treatment has not been formulated. Complete resection remains the only curative option for localized disease, but despite optimal surgery, CCSLTGT typically shows highly aggressive behavior with a high rate of local recurrence, metastases, and death from disease. The hallmark of CCSLTGT is the presence of EWSR1-CREBI or EWSR1ATF1 gene fusions, detectable with reverse transcriptionpolymerase chain reaction (PCR). The aim of this study was to assess all referred cases of CCSLTGT, and document the pathological features, treatment and outcome of these patients. Patients and Methods: We retrospectively reviewed all cases of histologically- and molecularly-confirmed CCSLTGT with EWSR1-CREB1 or EWSR1-ATF1 fusions at our tertiary sarcoma center, between 2009 and 2016. Results: We assessed six patients diagnosed with CCSLTGT. In a median follow-up of 8 months, all patients received surgery, and additionally one patient was treated with chemotherapy and had progressive disease. Five of six patients experienced
\end{abstract}

This article is freely accessible online.

Correspondence to: Robin L. Jones, Sarcoma Unit, The Royal Marsden NHS Foundation Trust, 203 Fulham Road, London, SW3 6JJ U.K. Tel: +44 0207352 8171, Fax: +44 0208082113, e-mail: robin.jones4@nhs.net

Key Words: Clear cell sarcoma-like of the gastrointestinal tract, gastrointestinal neuroectodermal tumor, outcome, pathology, genetics, EWSR1-CREB1 fusion, EWSR1-ATF1 fusion, treatment. recurrence or progression of disease and 4 of 6 patients died of disease. Conclusion: Our study confirms that CCSLTGT is a very rare aggressive sarcoma subtype with a very poor outcome. Greater international collaboration is required to obtain a better understanding of this disease.

Clear cell sarcoma-like tumor of the gastrointestinal tract (CCSLTGT) is an extremely rare mesenchymal tumor arising from the gastrointestinal tract, particularly the small bowel, stomach and large bowel (1). It has never been described outside the abdominal cavity. It most frequently affects adolescents and young adults with an equal gender distribution. The clinical presentation is often associated with tumor ulceration and nonspecific symptoms such as rectal bleeding, anemia and bowel obstruction. CCSLTGT is characterized by highly aggressive clinical behavior, with a high risk of recurrence and metastatic disease. There are few clinical data regarding this sarcoma type, but reported metastatic sites include the liver, lymph nodes and other intra-abdominal sites (2).

This entity was first described in 2003 by Zambrano et al. (3), who described six cases of a biologically-aggressive neoplasm affecting sites exclusively within the gastrointestinal tract which showed similarities to soft tissue clear cell sarcoma (CCS), also referred to as clear cell sarcoma of soft parts or conventional-type clear cell sarcoma, which typically affects extremity deep soft tissue sites, particularly around the foot and ankle $(4,5)$.

The genetic hallmark of CCS and CCSLTGT is the presence of translocations involving the EWSRl gene. EWSR 1 rearrangements have been described in many clinically and histologically different sarcomas, including desmoplastic small round cell tumor, Ewing sarcoma, extraskeletal myxoid chondrosarcoma, myxoid liposarcoma, angiomatoid fibrous histiocytoma and primary pulmonary myxoid sarcoma (4-6). The most frequent translocation in soft tissue CCS is $\mathrm{t}(12: 22)(\mathrm{q} 13 ; \mathrm{q} 12)$ resulting in the fusion 
Table I. Clinical characteristics of patients with clear cell-like tumor of gastrointestinal tract.

\begin{tabular}{|c|c|c|c|c|c|c|c|c|c|c|c|c|c|}
\hline $\begin{array}{l}\text { Patient } \\
\#\end{array}$ & Age & Gender & $\begin{array}{c}\text { Site } \\
\text { of } \\
\text { primary }\end{array}$ & $\begin{array}{l}\text { Status at } \\
\text { diagnosis }\end{array}$ & $\begin{array}{l}\text { Lymph } \\
\text { node } \\
\text { met }\end{array}$ & $\begin{array}{c}\text { Distant } \\
\text { met }\end{array}$ & $\begin{array}{c}\text { Surgery of } \\
\text { primary } \\
\text { disease }\end{array}$ & $\begin{array}{l}\text { Surgical } \\
\text { margins }\end{array}$ & $\begin{array}{l}\text { Recurrence } \\
\quad \text { (Mo) }\end{array}$ & $\begin{array}{c}\text { Site } \\
\text { of } \\
\text { recurrence }\end{array}$ & $\begin{array}{l}\text { Surgery } \\
\text { at } \\
\text { recurrence }\end{array}$ & $\begin{array}{l}\text { Chemo- } \\
\text { therapy }\end{array}$ & $\begin{array}{c}\text { Last FU } \\
\text { status } \\
(\mathrm{Mo})\end{array}$ \\
\hline 1 & 59 & F & Stomach & $\begin{array}{l}\text { Locally } \\
\text { advanced }\end{array}$ & $5 / 25$ & & $\begin{array}{c}\text { Subtotal } \\
\text { gastrectomy and } \\
\text { nodal dissection }\end{array}$ & Negative & $\begin{array}{l}\text { Yes } \\
(11)\end{array}$ & Liver met & No & Yes & $\begin{array}{l}\text { DOD } \\
(18)\end{array}$ \\
\hline 2 & 28 & $\mathrm{~F}$ & $\begin{array}{l}\text { Small } \\
\text { bowel }\end{array}$ & Localized & & & $\begin{array}{l}\text { Wide local } \\
\text { resection }\end{array}$ & Negative & $\begin{array}{l}\text { Yes } \\
(109)\end{array}$ & $\begin{array}{l}\text { Mesenteric } \\
\text { lymph nodes }\end{array}$ & Yes & No & $\begin{array}{l}\text { NED } \\
(161)\end{array}$ \\
\hline 3 & 27 & $\mathrm{~F}$ & $\begin{array}{l}\text { Small } \\
\text { bowel }\end{array}$ & Metastatic & & $\begin{array}{l}\text { Lung and } \\
\text { peritoneum }\end{array}$ & Resection & NA & $\begin{array}{l}\text { Yes } \\
(2)\end{array}$ & $\begin{array}{l}\text { Lung and } \\
\text { peritoneum }\end{array}$ & No & NA & $\begin{array}{l}\text { DOD } \\
(4)\end{array}$ \\
\hline 4 & 33 & M & $\begin{array}{l}\text { Small } \\
\text { bowel }\end{array}$ & $\begin{array}{l}\text { Locally } \\
\text { advanced }\end{array}$ & $3 / 11$ & & $\begin{array}{c}\text { Wide local } \\
\text { resection and } \\
\text { nodal dissection }\end{array}$ & Negative & $\begin{array}{l}\text { Yes } \\
\text { (2) }\end{array}$ & $\begin{array}{c}\text { Mesenteric } \\
\text { nodes and } \\
\text { liver met }\end{array}$ & No & No & $\begin{array}{l}\text { DOD } \\
(8)\end{array}$ \\
\hline 5 & 48 & M & $\begin{array}{l}\text { Small } \\
\text { bowel }\end{array}$ & Localized & & & Resection & NA & $\begin{array}{l}\text { Yes } \\
\text { (NA) }\end{array}$ & NA & NA & NA & $\begin{array}{c}\text { DOD } \\
\text { (unknown) }\end{array}$ \\
\hline 6 & 27 & M & $\begin{array}{l}\text { Small } \\
\text { bowel }\end{array}$ & Metastatic & & $\begin{array}{l}\text { Multi- } \\
\text { nodular, } \\
\text { peritoneum }\end{array}$ & $\begin{array}{l}\text { Wide local } \\
\text { resection, } \\
\text { nodal dissection } \\
\text { and peritoneal } \\
\text { nodule resection }\end{array}$ & Negative & No & NA & NA & NA & $\begin{array}{c}\text { NED } \\
(2)\end{array}$ \\
\hline
\end{tabular}

Mo: Months from diagnosis; FU: follow up; NA: not assessable; DOD: dead of disease; NED: no evidence of disease; met: metastases.

of EWSRI and ATF1 genes (7), while another translocation $\mathrm{t}(2 ; 22)(\mathrm{q} 32.3 ; \mathrm{q} 12)$, results in EWSR1-CREB1 fusion. Despite both conventional-types CCS and CCSLTGT displaying EWSR1 rearrangements involving either ATF1 or CREB 1 genes, CCSLTGT more frequently appears to harbor EWSRICREB1 fusions (8).

There are very few published data regarding the clinical behavior and outcomes of histologically and molecularly proven CCSLTGT. In particular, there have been no previous studies evaluating the use of chemotherapy in this histological subtype. Therefore, the aim of this study was to document the clinical outcome of patients treated at a single referral center to serve as a benchmark for future studies.

\section{Patients and Methods}

Case selection. Institutional approval was obtained prior to commencing the study. A retrospective search of the prospectively maintained Royal Marsden Sarcoma Unit database was performed to identify patients with CCSLTGT treated between 2003 and 2016. We chose the time frame for our study based on the year this entity was first described to the present.

Patient age, gender, date of diagnosis, disease site, therapy administered, and date of last follow-up or death were obtained from the database or electronic patient record. Descriptive statistics were employed. The diagnosis was confirmed in all cases by experienced soft tissue pathologists (CF and KT). Standard techniques were employed for immunohistochemistry as described elsewhere. Routinely, the following markers were tested for the patients included in this study; S100, MelanA, HMB45, cytokeratins, CD34, desmin, SMA, h-caldesmon.
Molecular and molecular cytogenetic analysis. For fluorescence in situ hybridization (FISH), 2- $\mu$ m-thick formalin fixed and paraffin embedded sections were dewaxed overnight at $60^{\circ} \mathrm{C}$, treated with hot buffer wash at $80^{\circ} \mathrm{C}$ (2-3 hours) then proteolytic enzyme treatment at $37^{\circ} \mathrm{C}$, and finally washed in distilled water and an alcohol series before addition of EWSR1 break-apart probe (Vysis, Abbott Laboratories Ltd, Maidenhead, UK). Hybridization was performed overnight according to the manufacturer's protocol. Reverse transcription-polymerase chain reaction (RT-PCR) was performed to assess for EWSR1-CREB1 and EWSR1-ATF1 fusion transcripts according to standard and previously described methods (9). Descriptive statistics were used.

\section{Results}

Clinical results. Six consecutive patients diagnosed with CCSLTGT were identified from the Royal Marsden Sarcoma Unit database. Three patients were female and three male, and the median age at diagnosis was 30 years (range $=27-59$ years). Five patients had tumors arising from the small bowel wall (three from ileum and two from jejunum) and one from the gastric wall. The clinical characteristics of these patients are displayed in Table I.

Two patients (Patients 2 and 5; Table I) presented with localized tumors at diagnosis and two (Patients 1 and 4) had locally advanced disease with lymph nodal involvement. One patient (Patient 3) presented with peritoneal and lung metastases. Patient 6 presented with ulcerating jejunal mass and solitary peritoneal metastatic nodule, which was resected with none of 21 lymph nodes involved. Patient 1 had previously been treated at the age of 13 years for 

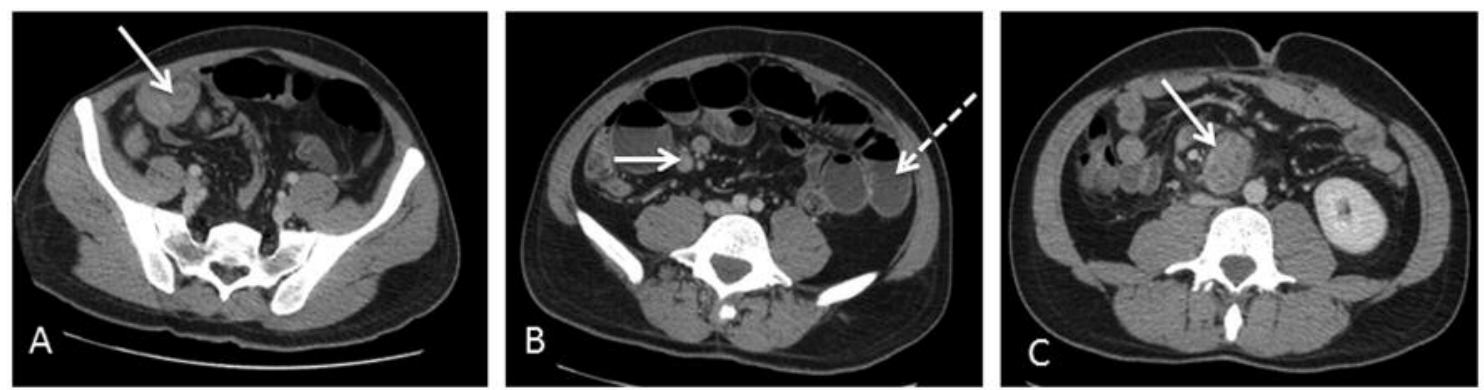

Figure 1. Contrast enhanced CT scans (Patient 4). Enhancing polypoid distal small bowel mass (A, arrow) causing intussuception with proximal dilated loops of small bowel ( $B$, dashed arrow) and abnormal rounded nodes in the draining mesentry (B, arrow). Recurrent mesenteric soft tissue mass $(C$, arrow).

hepatoblastoma, with six cycles of PLADO regimen (cisplatin and doxorubicin) chemotherapy followed by partial hepatectomy and radiotherapy in the context of a Society of Pediatric Oncology Liver Cancer (SIOPEL) study, as reported in a study by Thway et al. (10).

All patients underwent wide-local excision of the primary tumor. Patients 3, 4 and 5 underwent emergency abdominal surgery due to bowel obstruction (Figure 1A-B). Follow-up information was available for five patients and the mean follow-up was 8 months (range=2-161 months).

Five of six patients developed recurrent or progressive disease after a median duration of 6.5 months (range $=2-109$ months). Patients 1 and 4 developed liver and regional lymph node metastases (Figure $1 \mathrm{C}$ ) and, as previously mentioned, Patient 3 presented with peritoneal and lung metastases, and experienced progressive disease. Patient 2 had a family history of neurofibromatosis type 1 (NF1), and had been originally diagnosed elsewhere with malignant peripheral nerve sheath tumor or melanoma arising from the small bowel in 2002. In 2011 she experienced recurrent disease in mesenteric lymph nodes that was resected, with a subsequent diagnosis of CCSLTGT and retrospective diagnosis of CCSLTGT on the primary neoplasm (Figure 2). Patient 6 was diagnosed with a renal cell carcinoma (RCC) at the age of 55 years. Patient number 1 received three cycles of single agent chemotherapy (dacarbazine $800 \mathrm{mg} / \mathrm{m}^{2}$ ), with progression. At last follow-up, four patients had died of disease and two patients were alive with no evidence of disease.

\section{Discussion}

CCSLTGT is a very rare sarcoma subtype that has only relatively recently been described as a separate entity from conventional soft tissue clear cell sarcoma. While its etiology remains unknown, based on S100 protein and SOX10 protein positivity and the absence of melanocytic differentiation, it has been suggested that it could originate from primitive

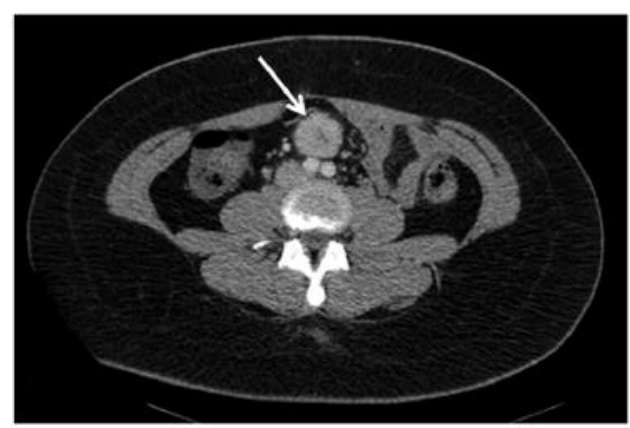

Figure 2. Contrast enhanced CT scan (Patient 2) demonstrates an avidly enhancing central mesenteric recurrence (arrow).

neural crest cells, with some groups renaming it as gastrointestinal neuroendocrine tumor (GNET) (11). Antonescu et al. also speculated a possible gastrointestinal neuroectodermal precursor cell which has lost the ability to differentiate along the melanocytic lineage (8). However, CCSLTGT is now established as a translocation-associated tumor characteristically harboring EWSRI-CREBI or EWSRI-ATF 1 gene fusions and without recapitulation of a normal cell of origin or line of differentiation.

Clinically, CCSLTGT is characterized by an extremely aggressive course with a very high rate of development of metastatic disease and short survival. CCSLTGT occurs predominantly in the small bowel, large bowel and stomach in young adults, growing as a transmural mass often associated with extensive ulceration. Reported metastatic sites include liver, peritoneum and lymph nodes $(2,8)$. Conventional CCS can metastasize to lung, bone and lymph nodes, and is, also, a very aggressive disease (12-14). Our case series of six patients with CCSLTGT indicates that this is a very aggressive sarcoma subtype, with 4 out of 6 patients succumbing to disease (a median survival of 8 months). However, our series includes also a long-term 
survivor. To date, no prognostic factors have been reported and the only suggested treatment is surgery. Data regarding systemic therapy and radiotherapy in CCSLTGT are very limited. One of the patients in our series developed progressive disease following 3 cycles of single-agent dacarbazine. Conventional-type clear cell sarcoma is chemoresistant (15), and our experience with one CCSLTGT patient suggests that this may be a relatively chemo-resistant subtype, as well. Clinical trials of novel agents should be offered to patients with this rare sarcoma subtype, particularly if there is an underlying biological rationale, in order to gain a better understanding of the disease. In addition, further collaborative retrospective studies are required to define the role of conventional chemotherapy and radiation therapy in this histological subtype.

While potential factors that may contribute to its cause are not known, in our series three patients had a personal or family history of cancer. In particular, Patient 1 had a history of hepatoblastoma in childhood and received chemotherapy and radiotherapy treatment, and low dose radiation therapy may potentially have contributed to the occurrence of CCSLTGT. The precise radiation therapy fields were not available for review, but the anatomic location of the CCSLTGT corresponded to the previously irradiated region (10). In accordance with this observation, there are other anecdotal reports which have correlated low dose radiotherapy given during childhood with CCSLTGT $(16,17)$. Patient 2 had a family history of NF1 (von Recklinghausen disease). NF1 is an autosomal dominantly inherited disorder causing inactivation of the NFI tumor suppressor gene on 17q11.2. Although NF1 is completely penetrant, it is characterized by a wide variety of clinical manifestations, including pigmented lesions, learning disabilities and a variety of neoplasms. It is known that patients with NF1 are at higher risk for developing soft tissue sarcomas, and although malignant peripheral nerve sheet tumor (MPNST) is the most common malignancy associated with NF1, patients have a higher predisposition for other soft tissue sarcomas $(18,19)$. In addition, Patient 6 had a family history of RCC. It is known that RCC is related to von Hippel-Lindau (VHL) tumor-suppressor gene inactivation which leads to constitutive activation of Hypoxia-inducible factor 1a (HIF1a) which can cause renal tumorigenesis (20). It has been recently demonstrated that $H I F-1 a$ genes are also involved in sarcoma metastasis (21). Familial RCC has been associated with several recurrent mutations located near the $V H L$ locus, including Polybromo-1 (PBRMI) and BRCAl-associated protein-1 $(B A P 1)(22,23)$. Mutations involving these two genes have also been described in sarcomas (24) and mesotheliomas (25). This suggests a possible involvement of these genes in the pathogenesis of different cancers, and a potential family genetic abnormality might be related to CCSLTGT.
Although CCSLTGT is extremely rare, it is likely that its frequency has been underestimated due to its lack of recognition by surgical pathologists, owing to its morphological and immunohistochemical overlap with a variety of neoplasms, such as conventional CCS, gastrointestinal stromal tumor, melanoma, malignant perivascular epithelioid cell neoplasm (PEComa) and clear cell carcinoma. Furthermore, an EWSRI rearrangement could be a partner in a wide variety of distinct sarcomas including Ewing sarcoma, desmoplastic small round cell tumor (DSRCT), myxoid liposarcoma and extraskeletal myxoid chondrosarcoma (5). Because of this, the finding of EWSRl rearrangement by FISH alone is not optimal for the diagnosis of this subtype, due to the potential morphological and immunohistochemical overlap of CCSLTGT with other malignant neoplasms that can occur intra-abdominally, such as Ewing sarcoma and DSRCT. The diagnosis of CCSLTGT should be confirmed by molecular assessment for EWSR1 rearrangement and for EWSR1-CREB1 and EWSR $1-A T F 1$ fusion transcripts in the correct clinical and pathological context (9).

In conclusion, our study confirms that CCSLTGT is a very rare aggressive sarcoma subtype with a very poor outcome. Greater international collaboration is required to obtain a better understanding of this disease as well as application of novel therapeutic agents, potentially towards downstream products of the characteristic EWSR1-CREBI or EWSRIATF 1 gene fusions. This study will provide useful clinical data for practicing physicians as well as providing a benchmark for further research.

\section{Conflicts of Interest}

The Authors have no conflicts of interest or funding to disclose.

\section{Acknowledgements}

Michela Libertini received support from European School of Oncology (ESO) within the ESO training programme 2016. The Authors acknowledge support from the NIHR Royal Marsden/ICR Biomedical Research Centre.

\section{References}

1 Fletcher CDM, Bridge JA, Hogendoorn PCW, Mertens F, eds: WHO classification of tumours of soft tissue and bone. Pathology and genetics of tumours of soft tissue and bone. 4th ed. Lyon, IARC Press, 2013.

2 Yegen G, Güllüoğlu M, Mete O, Onder S and Kapran Y: Clear cell sarcoma-like tumor of the gastrointestinal tract: A case report and review of the literature. Int J Surg Pathol 23(1): 6167, 2015.

3 Zambrano E, Reyes-Mugica M, Franchi A and Rosai J: An osteoclast-rich tumor of the gastrointestinal tract with features resembling clear cell sarcoma of soft parts: reports of 6 cases of a GIST simulator. Int J Surg Pathol 11(2): 75-81, 2003. 
4 Thway K, Nicholson AG, Lawson K, Gonzalez D, Rice A, Balzer B, Swansbury J, Min T, Thompson L, Adu-Poku K, Campbell A and Fisher C: Primary pulmonary myxoid sarcoma with EWSR1-CREB1 fusion: a new tumor entity. Am J Surg Pathol 35(11): 1722-1732, 2011.

5 Fisher C: The diversity of soft tissue tumours with EWSR1 gene rearrangements: a review. Histopathology 64(1): 134-150, 2014

6 Thway K and Fisher C: Angiomatoid fibrous histiocytoma: The current status of pathology and genetics. Arch Pathol Lab Med 139(5): 674-682, 2015

7 Bridge JA, Borek DA, Neff JR and Huntrakoon M: Chromosomal abnormalities in clear cell sarcoma. Implications for histogenesis. Am J Clin Pathol 93(1): 26-31, 1990.

8 Antonescu CR, Nafa K, Segal NH, Cin PD and Ladanyi M: EWS-CREB1: A recurrent variant fusion in clear cell sarcomaassociation with gastrointestinal location and absence of melanocytic differentiation. Clin Cancer Res 12(18): 5356-5362, 2006.

9 Thway K, Rockcliffe S, Gonzalez D, Swansbury J, Min T, Thompson L and Fisher C: Utility of sarcoma-specific fusion gene analysis in paraffin-embedded material for routine diagnosis at a specialist centre. J Clin Pathol 63(6): 508-512, 2010.

10 Thway K, Judson I and Fisher C: Clear cell sarcoma-like tumor of the gastrointestinal tract, presenting as a second malignancy after childhood hepatoblastoma. Case Rep Med 2014: 984369, 2014

11 Stockman DL, Miettinen M, Suster S, Spagnolo D, DominguezMalagon H, Hornick JL, Adsay V, Chou PM, Amanuel B, Vantuinen $\mathrm{P}$ and Zambrano EV: Malignant gastrointestinal neuroectodermal with a reappraisal of clear cell sarcoma-like tumors of the gastrointestinal tract. Am J Surg Pathol 36(6): 857868,2012

12 Deenik W, Mooi WJ, Rutgers EJ, Peterse JL, Hart AA and Kroon BB: Clear cell sarcoma (malignant melanoma) of soft parts: A clinicopathologic study of 30 cases. Cancer 86(6): 969975, 1999.

13 Hocar O, Le Cesne A, Berissi S, Terrier P, Bonvalot S, Vanel D, Auperin A, Le Pechoux C, Bui B, Coindre JM and Robert C: Clear cell sarcoma (malignant melanoma) of soft parts: a clinicopathologic study of 52 cases. Dermatol Res Pract 2012: 984096, 2012.

14 Bianchi G, Charoenlap C, Cocchi S, Rani N, Campagnoni S, Righi A, Frisoni T and Donati DM: Clear cell sarcoma of soft tissue: a retrospective review and analysis of 31 cases treated at Istituto Ortopedico Rizzoli. Eur J Surg Oncol 40(5): 505-510, 2014.

15 Jones RL, Constantinidou A, Thway K, Ashley S, Scurr M, AlMuderis O, Fisher C, Antonescu CR, D'Adamo DR, Keohan ML, Maki RG and Judson IR: Chemotherapy in clear cell sarcoma. Med Oncol 28(3): 859-863, 2011.

16 Yang JC, Chou AJ, Oeffinger KC, La Quaglia MP and Wolden SL: Clear cell sarcoma of the gastrointestinal tract after very low-dose therapeutic radiation therapy: a case report. J Pediatr Surg 47(10): 1943-1945, 2012.
17 Balkaransingh P, Saad SA, Govil SC, Thind PK, Ballance CM and Weiss AR: Clear cell sarcoma of the gastrointestinal tract presenting as a second malignant neoplasm following neuroblastoma in infancy. Pediatr Blood Cancer 58(3): 481-482, 2012.

18 Ferrari A, Bisogno G, Macaluso A, Casanova M, D'Angelo P, Pierani P, Zanetti I, Alaggio R, Cecchetto G and Carli M: Softtissue sarcomas in children and adolescents with neurofibromatosis type 1. Cancer 109(7): 1406-1412, 2007.

19 Tardío JC, Machado I, Navarro L, Idrovo F, Sanz-Ortega J, Pellín A and Llombart-Bosch A: Ewing-like sarcoma with CICDUX4 gene fusion in a patient with neurofibromatosis type 1. A hitherto unreported association. Pathol Res Pract 211(11): 877$882,2015$.

20 Baldewijns MM, Van Vlodrop IJH, Vermeulen PB, Soetekouw PMMB, Van Engeland M and De Bruïne AP: VHL and HIF signalling in renal cell carcinogenesis. J Pathol 221(2): 125-138, 2010.

21 El-Naggar AM, Veinotte CJ, Cheng H, Grunewald TG, Negri GL, Somasekharan SP, Corkery DP, Tirode F, Mathers J, Khan D, Kyle AH, Baker JH, LePard NE, McKinney S, Hajee S, Bosiljcic M, Leprivier G, Tognon CE, Minchinton AI, Bennewith KL, Delattre O, Wang Y, Dellaire G, Berman JN and Sorensen PH: Translational activation of HIF1 $\alpha$ by YB-1 promotes sarcoma metastasis. Cancer Cell 27(5): 682-697, 2015.

22 Piva F, Santoni M, Matrana MR, Satti S, Giulietti M, Occhipinti G, Massari F, Cheng L, Lopez-Beltran A, Scarpelli M, Principato G, Cascinu S and Montironi R: AP1, PBRM1 and SETD2 in clear-cell renal cell carcinoma: molecular diagnostics and possible targets for personalized therapies. Expert Rev Mol Diagn 15(9): 1201-1210, 2015.

23 Farley MN, Schmidt LS, Mester JL, Pena-Llopis S, PaviaJimenez A, Christie A, Vocke CD, Ricketts CJ, Peterson J, Middelton L, Kinch L, Grishin N, Merino MJ, Metwalli AR, Xing C, Xie XJ, Dahia PLM, Eng C, Linehan WM and Brugarolas JA: Novel germline mutation in BAP1 predisposes to familial clear-cell renal cell carcinoma. Mol Cancer Res 11(9): 1061-1071, 2013.

24 Li L, Fan X-S, Xia Q-Y, Rao Q, Liu B, Yu B, Shi QL, Lu ZF and Zhou XJ: Concurrent loss of INI1, PBRM1, and BRM expression in epithelioid sarcoma: implications for the cocontributions of multiple SWI/SNF complex members to pathogenesis. Hum Pathol 45(11): 2247-2254, 2014.

25 Henderson DW, Reid G, Kao SC, van Zandwijk N and Klebe S: Challenges and controversies in the diagnosis of malignant mesothelioma: Part 2. Malignant mesothelioma subtypes, pleural synovial sarcoma, molecular and prognostic aspects of mesothelioma, BAP1, aquaporin-1 and microRNA. J Clin Pathol 66(10): 854-861, 2013.
Received December 17, 2017

Revised January 16, 2018

Accepted January 17, 2018 